\title{
Continuous combined microwave and hot air treatment of apples for fruit fly (Bactrocera tryoni and B. jarvisi) disinfestation
}

\author{
T.V. Gamage ${ }^{\text {a,* }}$, P. Sanguansri a ${ }^{\text {a }}$ P. Swiergon ${ }^{\text {a }}$, M. Eelkema ${ }^{\text {b }}$, P. Wyatt ${ }^{\text {b }}$, P. Leach ${ }^{\text {b }}$, \\ D.L.J. Alexander ${ }^{c}$, K. Knoerzer ${ }^{a}$ \\ a CSIRO Food and Nutrition Flagship, 671 Sneydes Road, Werribee, VIC 3030, Australia \\ ${ }^{\mathrm{b}}$ Horticulture and Forestry Science, Agri-Science Queensland, Department of Agriculture, Fisheries and Forestry, Ecosciences Precinct, GPO Box 267, Brisbane, QLD 4001, Australia \\ c CSIRO Computational Informatics, Gate 5 Normanby Road, Clayton, VIC 3168, Australia
}

\section{A R T I C L E I N F O}

\section{Article history:}

Received 2 September 2014

Received in revised form 25 February 2015

Accepted 26 February 2015

Available online 8 March 2015

\section{Keywords:}

Fruit fly

Microwave

Fruit

Disinfestation

Insect

Non chemical

Bactrocera tryoni

Bactrocerajarvisi

Apples

Electromagnetic

\begin{abstract}
A B S T R A C T
Apples at $24 \pm 2{ }^{\circ} \mathrm{C}$ were heated in a pilot scale hot air assisted $\left(40^{\circ} \mathrm{C}\right)$ continuous pentagonal microwave system, to evaluate the effectiveness of this treatment on insect mortality (variety Mutsu) and fruit quality (variety Granny Smith). An average temperature of $53.4 \pm 1.3^{\circ} \mathrm{C}$ at core, bottom and flesh of the apple was recorded at the end of the treatment. One hundred percent mortality of the most tolerant stage of Queensland fruit fly (Bactrocera tryoni, Froggatt) and Jarvis's fruit fly (Bactrocera jarvisi, Tryon), were observed when the Mortality value $\left(\mathrm{M}_{52}\right.$, equivalent time of isothermal treatment at $52{ }^{\circ} \mathrm{C}$ ) at the slowest heating point applicable for each experiment was $\geq 50$ min and $\geq 37$ min, respectively.

Results: showed that microwave heat treatment is effective for insect disinfestation without any adverse impact on total soluble solids, flesh or peel firmness of the treated apples. The treated apples recorded a significantly higher $\mathrm{pH}$ and lower ion leakage than the untreated apples after 3 or 4 weeks. Therefore, the microwave heat treatment has the potential to be developed as an alternative chemical free quarantine treatment against economically significant insect pests.

Industrial relevance: Hot air assisted microwave heating of fruits and vegetables, is more cost effective compared to vapour heat treatment and ionising radiation for disinfestation of insects. Microwave treatment is environmentally friendly compared to fumigation and chemical treatments. Hot air assisted microwave disinfestation can be performed at farms or centralised pack houses since the capital cost would be comparatively lower than vapour heat or ionising radiation treatments.
\end{abstract}

Crown Copyright @ 2015 Published by Elsevier Ltd. All rights reserved.

\section{Introduction}

Fruit fly (FF) infestation is a major concern to Australia's $\$ 6.9$ billion horticulture industry, which benefits from both domestic and international trade (Plant Health Australia, 2008; Sutherst, Collyer, \& Yonow, 2000). Apples are ranked among the top five horticultural commodities exported from Australia and are a host for Bactrocera tryoni (Q-fly) and Bactrocera jarvisi (Jarvisi fly) fruit flies. Quarantine regulations imposed by the importing countries restrict Australia's fresh fruit export market opportunities, hence access to export markets for fruit produced in FF infested areas is dependent on both the effective management of insect pests on farm and acceptable postharvest risk management strategies. Disinfestation treatments currently used for horticultural produce include the use of fumigants such as methyl bromide (MeBr) (Australian Government, 2014), pesticide dipping solutions such as fenthion,

\footnotetext{
* Corresponding author. Tel.: +613 9731 3471; fax: +61397313201.

E-mail address: thambaramala.gamage@csiro.au (T.V. Gamage).
}

controlled atmosphere storage, cold and heat treatments (Amstrong \& Mangan, 2007), ionising radiation (ISPM No 18, 2003; ISPM No 28 Part 3 (2009)), treatment with electromagnetic energy (Tang, Ikediala, Wang, Hansen, \& Cavalieri, 2000) and combinations of these treatments (Varith, Sirikajornjaru, \& Kiatsiriroat, 2007).

The Montreal protocol has mandated the complete removal of $\mathrm{MeBr}$ from use by January 2005 except for quarantine and pre-shipment applications (Australian Government, 2014). Australia has also limited its use of dimethoate (Anon., 2011). As a result, there is a sense of urgency for the development of new, environmentally sustainable, nonchemical treatments for insect disinfestation processes that may be easily implemented and commercialised.

Heat treatments (hot water dips, vapour heat or hot dry air) are common alternatives to chemical disinfestations treatments (Corcoran, Heather, \& Heard, 1993). Disinfestation occurs through heat conduction from the fruit surface to the core and maintaining it for a certain time. The relatively low thermal conductivity of fruit limits the conduction rate, requiring prolonged heat exposure ( $>5 \mathrm{~h}$ ) and, therefore, quality loss (Hansen, 1992). 
The deterioration in fruit quality can be minimised by high temperature short time (HTST) treatments for inactivation of insects. Ikediala, Tang, and Wig (2000) and Tang et al. (2000) using an experimental heating block system, reported that heating fruit at a rate of $20^{\circ} \mathrm{C} / \mathrm{min}$ to a target temperature of $54{ }^{\circ} \mathrm{C}$ for 1.2 min resulted in $100 \%$ mortality of codling moth whilst having a minimal impact on fruit quality.

The use of non-ionising radiation in the form of electromagnetic waves such as radio frequency and microwaves for faster heating of fruits has been the subject of several recent studies (Tang et al., 2000; Sharp, Robertson, \& Preisler, 1999; Ekman \& Pristijono, 2010). Electromagnetic waves penetrate the fruit and the energy is internally dissipated into thermal energy volumetrically heating the fruit. Whilst even heating of the whole fruit is theoretically possible, non-uniform electric fields in microwave cavities, heterogeneous product structure, varying thermal and dielectric properties of the fruit components, among other microwave inherent factors, often cause uneven heating during the treatment process (Ikediala et al., 2000; Knoerzer, Regier, \& Schubert, 2008).

Previous studies have focused on the use of microwaves in small scale batch operations. No studies have been reported on continuously operating larger scale microwave systems. Therefore, the objective of this study was to demonstrate the efficacy of a continuously operated, pilot scale, hot air assisted microwave heating process developed to evenly heat apples for the disinfestation of fruit fly eggs and larvae whilst maintaining acceptable product quality.

\section{Materials and methods}

\subsection{Pentagonal microwave system}

A hot air assisted microwave tunnel system with a pentagonal crosssection (Figs. 1 and 2) was used for all product treatments. The system has a total of $15 \times 1 \mathrm{~kW}$ magnetrons operating at $2.45 \mathrm{GHz}$. Three magnetrons are evenly distributed along each face of the pentagon along the $1.5 \mathrm{~m}$ tunnel. Each magnetron can be independently controlled by a programmable logic controller (PLC). The total length of the tunnel, including pre- and post-heating sections, is $2.8 \mathrm{~m}$. The system is a modified and enhanced version of the design as described by Tran (1984).

An auxiliary hot air system with an independently controlled heater and a fan is attached to the microwave system. This was done via two polypropylene tubes attached at both ends of the tunnel to introduce heated air into the tunnel at a maximum air velocity of $3 \mathrm{~m} / \mathrm{s}$.

Fruit was subjected to slight pre- and post-heating in the tunnel section outside of the microwave through convection heating where hot air is blown inwards from both sides of the tunnel. A variable speed conveyor belt moves the product through the microwave tunnel.

\subsection{Apples}

Organically grown Mutsu apples were obtained by the Cairns research station of Queensland DAFF (Department of Agriculture, Fisheries

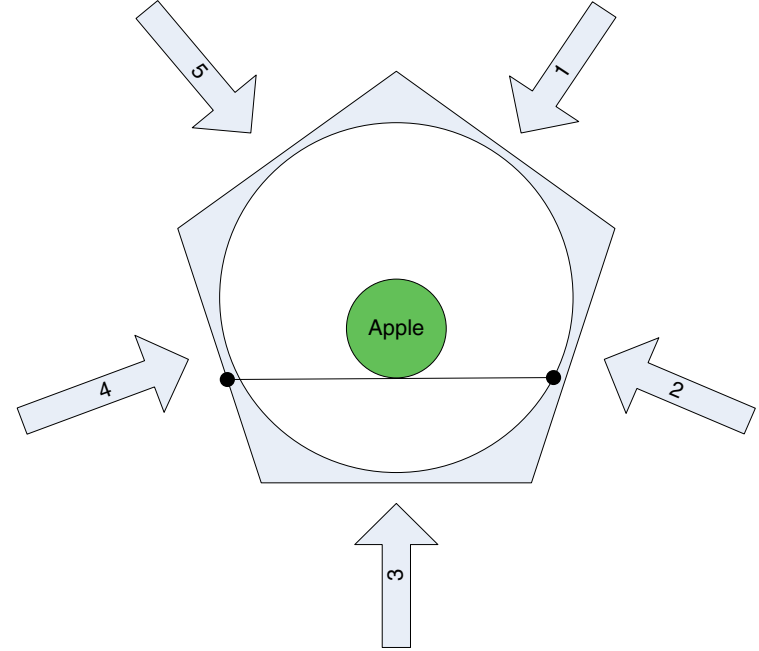

Fig. 2. Cross-section of the microwave tunnel. Arrows indicate the position of the magnetrons on each side.

and Forestry) from United Organics (Brisbane, QLD, Australia) for fruit fly disinfestation trials. Weights varied from 109-151 g for control fruit and 112-183 $\mathrm{g}$ for treated fruit.

Granny Smith apples, with a weight of $139 \pm 6 \mathrm{~g}$ and an initial firmness of $68.4 \pm 6.0 \mathrm{~N}$ (determined by the compression method) were obtained from Summer Snow Orchards (Officer, VIC, Australia) for the quality evaluation trials. The apples were stored at $4 \pm 1{ }^{\circ} \mathrm{C}$ and removed from cold storage to equilibrate to ambient temperatures of $22 \pm 2{ }^{\circ} \mathrm{C}$ for $8 \mathrm{~h}$ prior to use. This was done to raise their internal temperatures close to actual harvesting temperatures.

\subsection{Microwave pulse programme}

A set of three magnetrons on a side of the pentagon was activated to give a burst of microwave energy, followed by an off-cycle to allow for internal temperature equilibration in the apple. The cycle was repeated in a clockwise direction during product treatment. The conveyor belt used to transport the apples was programmed to only move forward at a fixed speed when magnetrons are activated. The process was designed to provide a temperature increase to approximately $54^{\circ} \mathrm{C}$, which required a specific energy input of $100-120 \mathrm{~kJ} / \mathrm{kg}$. The same programme is used for both the disinfestation and quality trials.

\subsection{Measurement of temperature inside apples and mortality time $\left(M_{52}\right)$}

A fibre optic temperature measurement system with $4 \times 6 \mathrm{~m}$ fibres (Neoptix Inc., Quebec, Canada) was used to record real time temperature changes inside the apples as it moved through the microwave tunnel. The fibre tips were inserted into selected apples (approximately

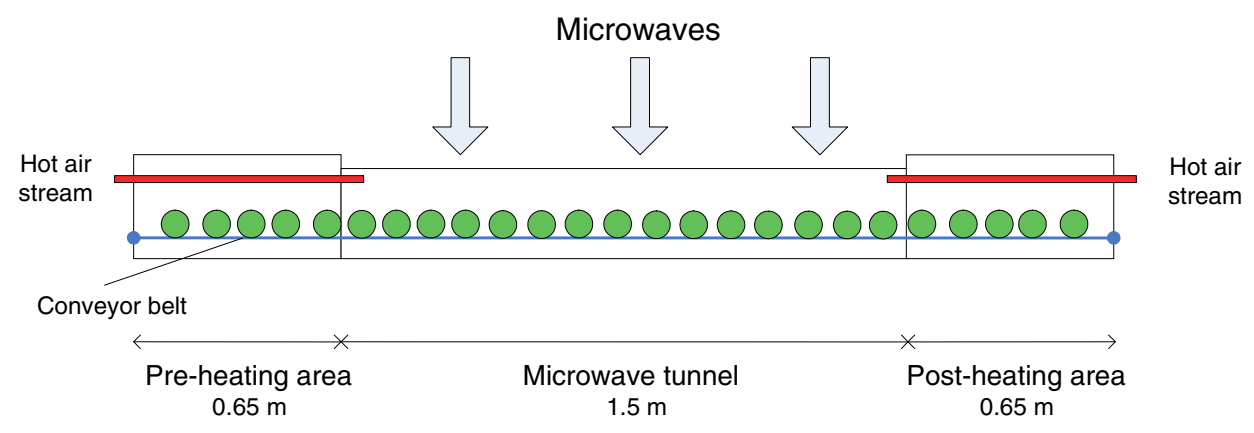

Fig. 1. Side view of the pilot scale pentagonal microwave unit. Arrows indicate the magnetron positioning along each side of the pentagonal microwave tunnel. 
one every 30 apples, selected as being representative for all treated apples) as shown in Fig. 3. The top and bottom fibre optic sensors were inserted $\sim 2 \mathrm{~mm}$ under the skin; the optic fibre placed in the flesh was approximately halfway between the core and the skin. Temperatures were logged using a Reflex 4 channel fibre optic conditioner (Neoptix Inc., Quebec, Canada). Temperature measurements were recorded at 1 second intervals and the temperature data were used to calculate the equivalent time at a target temperature of $52{ }^{\circ} \mathrm{C}$ (mortality time $\mathrm{M}_{52}$ ).

$\mathrm{M}_{52}$ is defined as equivalent time in minutes at $52{ }^{\circ} \mathrm{C}$ required to achieve $100 \%$ mortality (Tang et al., 2000) and was calculated using Eq. (1):

$M_{52}=\int_{0}^{t} 10^{\frac{T(t)-52^{\circ} \mathrm{C}}{z}} d t$

where $\mathrm{T}(\mathrm{t})$ is the transient temperature profile, $\mathrm{t}$ is the time ( $\min )$ and $\mathrm{z}$ is the temperature change $\left(\right.$ in ${ }^{\circ} \mathrm{C}$ ) required to change the value of insect mortality by a factor of 10 . Studies conducted by Gazit, Rossler, Wang, Tang, and Lurie (2004) recorded the $\mathrm{z}$ values for Mediterranean fruit fly (Diptera: Tephritidae; Ceratitis capitata, Weidemann) eggs and 3rd instar larvae of 4.1 and $3.6^{\circ} \mathrm{C}$, respectively. Given the similarity between the Mediterranean fruit fly and the B. tryoni (Birla et al., 2004; Ekman \& Pristijono, 2010) a $\mathrm{z}$ value of $4{ }^{\circ} \mathrm{C}$ was selected to represent both eggs and larvae for this study.

\subsection{Hot air assisted microwave treatment of infested apples}

The microwave system was preheated to 40 or $45^{\circ} \mathrm{C}$ for approximately 15 min prior to each experiment. This was done to minimise heat losses through the surface of the heated apples during the temperature equilibration stage of each microwave cycle. The apples were placed on a small plastic stand with four protruding rods and fed onto the conveyor belt with a gap of approximately $1 \mathrm{~cm}$ between them to facilitate air movement underneath and between the apples.

\subsection{Infestation of apples with B. tryoni and B. jarvisi fruit flies}

B. tryoni adults were obtained from a laboratory colony reared from collections of White Apple (Syzygium forte ssp. forte). B. jarvisi adults were obtained from a laboratory colony reared from a collection of Cocky Apple (Planchonia careya).

B. tryoni and B. jarvisi colonies were maintained at the Department of Agriculture, Fisheries and Forestry (DAFF) laboratories at Redden Street,

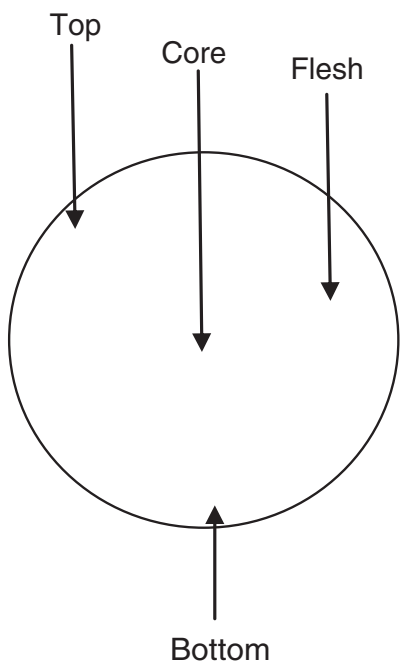

Fig. 3. Positioning of the fibre optic cables inside an apple.
Cairns, Queensland. Both colonies were reared on a carrot-based medium using the method of Heather and Corcoran (1985).

Approximately 15,000 adult flies with a male to female ratio of $1: 1$ were held in $620 \mathrm{~mm}$ cubic cages. The adult colonies were held in controlled environment rooms with artificial and natural light at set temperature and humidity of $26{ }^{\circ} \mathrm{C}$ and $70 \% \mathrm{RH}$ respectively.

Fruit was removed from cold storage a day prior to infesting and was held at $26^{\circ} \mathrm{C}$ and $70 \% \mathrm{RH}$. Fruit was punctured 50 times at the stem end and placed inside cages containing 15,000 mature adults from each species for periods of 30-60 min. One piece of fruit from each row of 6 was selected as a control and used to estimate the number of insects treated. Additional fruit was also infested for to estimate of the developmental stage of the insects during treatment. At each treatment time a sample was placed into a freezer to kill the insects, prior to removal from the fruit for examination under a dissecting microscope. The number of insects for each life stage was recorded.

Infested apples (control, MW treated, and apples for the identification of instars on day two) were placed inside cardboard boxes and sent from the QDAFF facility in Cairns (Queensland, Australia) by overnight courier to the CSIRO facilities in Coopers Plains (Queensland, Australia). Upon arrival at CSIRO, the apples were divided into two batches. The first batch was treated on the day of arrival, approximately $24 \mathrm{~h}$ after oviposition, whilst all insects were eggs. The second batch was kept at room temperature until the following day and treated approximated $48 \mathrm{~h}$ after oviposition when the eggs had begun to hatch and were treated as a mixture of mature eggs and first instar larvae.

\subsection{Fruit fly disinfestation trials}

A total of 60 apples for each replicate experiment were processed using the conditions described in Table 1. Apples were then allowed to cool at room temperature and transported to the QDAFF facility in Brisbane (Queensland, Australia). Each experiment was conducted at least three times.

\subsection{Assessment of fruit fly mortality}

On arrival at the QDAFF facility, the control and microwave treated apples were set up on gauzed plastic containers, over vermiculite, in ventilated plastic boxes. They were placed in controlled environment rooms at $26^{\circ} \mathrm{C}$ and $70 \% \mathrm{RH}$ to allow surviving insects to develop through to the pupal stage. The vermiculite was sieved 14-21 days after infestation and pupae collected. Untreated controls were used to estimate the number of insects treated in each trial and the surviving pupae from the treated fruit used to determine the efficacy of each treatment.

\subsection{Apple quality assessment trial}

\subsubsection{Control}

A batch of 50 apples was transported through the tunnel without the application of microwaves and heat to simulate the conveying procedure as described above for treatment $\mathrm{T}_{\mathrm{a}}$. The handling of the control samples before and after transporting through the microwave unit was similar to the treated apples.

Table 1

Process conditions used for fruit fly disinfestations trials.

\begin{tabular}{lllll}
\hline Treatment & $\begin{array}{l}\text { Tunnel air } \\
\text { temperature }\left({ }^{\circ} \mathrm{C}\right)\end{array}$ & $\begin{array}{l}\text { Recorded specific } \\
\text { energy }(\mathrm{kJ} / \mathrm{kg})\end{array}$ & Species & $\begin{array}{l}\text { No. of replicate } \\
\text { experiments }\end{array}$ \\
\hline $\mathrm{T}_{\mathrm{a}}$ & 40 & $112.4 \pm 4.0$ & B. tryoni & 3 \\
$\mathrm{~T}_{\mathrm{b}}$ & 40 & $108.8 \pm 2.2$ & B. jarvisi & 4 \\
$\mathrm{~T}_{\mathrm{c}}$ & 45 & $102.7 \pm 4.5$ & B. jarvisi & 7 \\
$\mathrm{~T}_{\mathrm{d}}$ & 45 & $101.0 \pm 4.9$ & B. jarvisi & 7 \\
\hline
\end{tabular}




\subsubsection{Treatment}

A batch of 50 apples was heat-treated using the pulse programme described in Section 2.3 for $\mathrm{T}_{\mathrm{a}}$. Apples were then either cooled in $4{ }^{\circ} \mathrm{C}$ water for $1 \mathrm{~h}$ (treatment 1 - hydro cooling) or allowed to cool down at room temperature for $15 \mathrm{~h}$ (treatment 2 ).

\subsubsection{Storage of apples}

Treated and control apples were placed in cardboard boxes with plastic fruit holding trays. Boxes were then stored in the dark in a well ventilated cold room at $4{ }^{\circ} \mathrm{C}$ for 4 weeks.

\subsection{Quality analyses}

Quality analyses of the treated and untreated apples were conducted immediately after removal from the cold room. Week zero apples were analysed after storage of the apples at $4{ }^{\circ} \mathrm{C}$ for $8 \mathrm{~h}$ post processing.

\subsubsection{Weight loss}

The weight of six labelled apples from each treatment was recorded at weekly intervals for four weeks. Weight loss of each apple at each time interval was calculated.

\subsubsection{Peel colour and internal browning}

Digital photographs were taken of the whole apples with a digital camera (C-300 ZOOM, Olympus Optical Co. Ltd., Japan). Apples were then cut along the diagonal axis for visual assessment of browning. Digital photographs of the cross section were also taken for comparison.

\subsubsection{Firmness}

The compression method was used to measure firmness of the peel. An Instron universal testing machine (Model 4501, Instron Corp., Ohio, USA) fitted with a $100 \mathrm{~N}$ load cell and a cylindrical, flat end probe with a diameter of $1 \mathrm{~cm}$ and a crosshead speed of $2 \mathrm{~mm} / \mathrm{min}$ was used. The firmness was determined by measuring the maximum force $(\mathrm{N})$ at the break point when the probe travelled $2 \mathrm{~mm}$ into the apple tissue.

The firmness test of the internal tissue was carried out on a $20 \mathrm{~mm}$ thick slice cut from the diagonal axis of an apple (Fig. 4) at four different positions. Three apples were evaluated per treatment at each time interval.

\subsubsection{Ion leakage}

A $15 \mathrm{~mm}$ slice was cut from the diagonal axis of an apple (Fig. 4). Five discs with a diameter of $1 \mathrm{~cm}$ were cut from the pericarp using a cork bore and transferred into a labelled glass bottle. The total weight of the 5 discs was recorded. The discs were washed with deionised water three times to ensure reading accuracy and prevent disturbance caused by background conductivity (Saltveit, 2002). Then, $23 \mathrm{~mL}$ of $0.3 \mathrm{M}$ mannitol was added to the 5 apple discs and shaken for $1 \mathrm{~h}$ at 65 cycles/min. After that, the electrical conductivity of the mannitol solution was measured and recorded using a MC-84 conductivity meter (TPS, Brisbane, Queensland, Australia). The discs in $0.3 \mathrm{M}$ mannitol solution were then heated in a glycol/water bath at $100{ }^{\circ} \mathrm{C}$ for $30 \mathrm{~min}$. The heated solution was allowed to cool at ambient temperature until it reached $\sim 25^{\circ} \mathrm{C}$ before taking the second electrical conductivity measurement. The ion leakage value (in \%) was calculated using Eq. (2):

$\%$ IonLeakage $=\frac{\sigma_{\text {init }}}{\sigma_{\text {postBoiling }}} * 100$

where $\sigma_{\text {init }}$ is the electrical conductivity in $\mathrm{S} / \mathrm{m}$ (pre-boiling) and $\sigma_{\text {postBoiling }}$ is the electrical conductivity in $\mathrm{S} / \mathrm{m}$ after the boiling step. Three apples were evaluated per treatment at each time interval.

\subsubsection{Total soluble solids (TSS)}

Apple pulp was homogenised using a hand held blender (Bamix, Mettlen, Switzerland). The Total Soluble Solid (TSS) of the clear juice was measured with a hand held refractometer (Delta refractometer, Bellingham and Stanly Ltd, Basingstoke, UK). Three apples were evaluated per treatment at each time interval.

\subsection{6. $\mathrm{pH}$}

The apple pulp pH was measured using a calibrated Radiometer Analytical pH meter (SAS, Villeurbanne Cedex, France). Three apples were evaluated per treatment at room temperature for each time interval.

\subsection{Statistical analysis}

Data was analysed by ANOVA using open source R software. Statistical tests were performed to detect the effects of treatment and storage time. Tests were also performed to check whether time effects were linear, quadratic or a higher order across the 16 weeks of storage, and whether these effects differed for apples given different treatments. $P$ values for the relevant tests are quoted.

\section{Results and discussion}

\subsection{Development of MW treatment}

Heating and resting/equilibration cycles were initially developed in a modified $1000 \mathrm{~W}$ commercial microwave unit (Menumaster, model
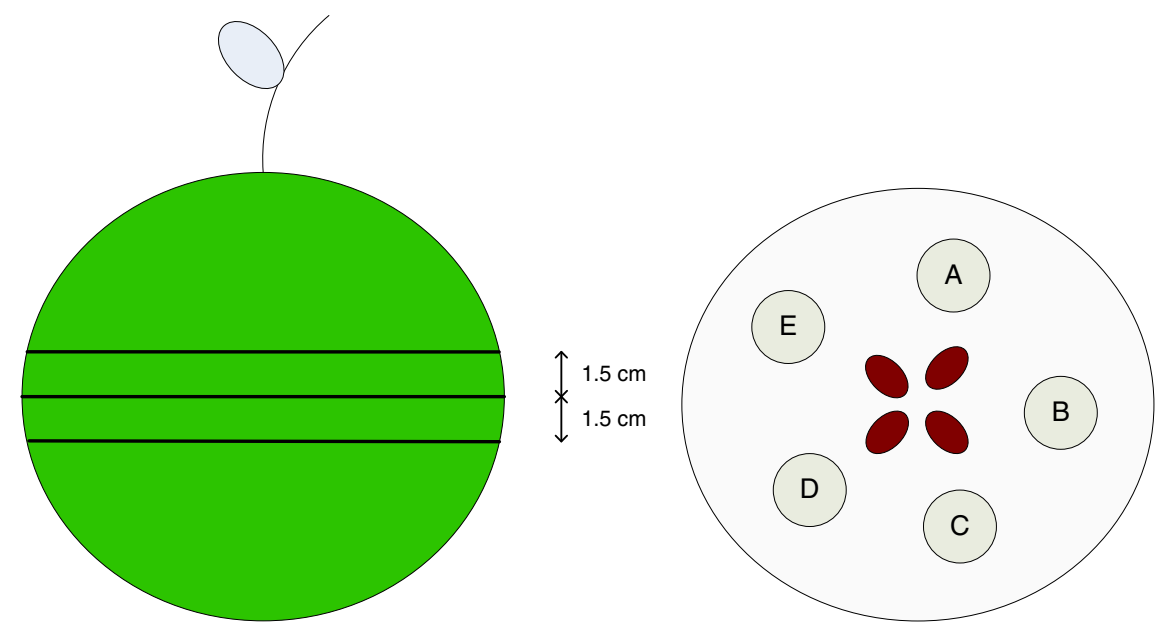

Fig. 4. Indication of slices at the diagonal axis of an apple and discs cut from a slice of an apple for ion leakage and firmness measurements. 
E\&U FS7 EVP, Mark Force Pty Ltd, Australia) using one apple at a time. At this stage, the requirement for a hot air assisted system to prevent loss of heat from the microwave treated apples was recognised. The use of hot air to obtain better temperature uniformity for microwave heated products was reported by Ikediala, Tang, Neven, and Drake (1999) and Knoerzer et al. (2008).

Pronounced temperature variations have been reported in microwave treated cherries of different sizes (Ikediala et al., 1999). Ohlsson (1983) reported that the weight of the treated material determines the absorption and dissipation of microwave energy. Likewise, this study showed that sorting of apples according to weight was essential in reproducible temperature results with minimum variation.

\subsection{Temperature and $M_{52}$}

A typical temperature distribution pattern within an apple is illustrated in Fig. 5. The temperature inside the apples equilibrated whilst moving through the microwave tunnel. Temperature increased slightly whilst the fruit was conveyed through the preheating areas. Once the fruit reached the microwave area, the temperature increased more rapidly. It was evident that the microwave heated the core and flesh region more than the surface. However, equilibration of the apple surface did occur after it moved through the first half of the tunnel by conduction of volumetric heat from the core and hot air which helped minimise heat loss from the surface. After leaving the microwave area, the fruit temperature was maintained close to the target temperature by the hot air in the post heating area.

The $\mathrm{M}_{52}$ values at the core were usually higher than at the flesh, bottom and top of the fruit. This effect was caused by the preferential microwave heating in the core, with temperatures peaking at each "on" cycle and also the longer exposure to higher temperatures compared to the other areas prior to reaching temperature uniformity across the fruit at the end of the microwave heating area in the tunnel.

Centre-focused heating (microwave processing at $915 \mathrm{MHz}$ ) was observed by Ikediala et al. (1999) in cherries with a diameter 1.9 to $3 \mathrm{~cm}$ (3.1 to $13.5 \mathrm{~g}$ ). Ohlsson and Risman (1978) and Ohlsson (1983) reported centre-focused heating of spherical objects with a diameter of 25 to $60 \mathrm{~mm}$. The apples used in our trials ranged from 60 to $80 \mathrm{~mm}$ in diameter and 115 to $141 \mathrm{~g}$ in weight and centre-focused heating was clearly an issue. This was mitigated by allowing time for temperature equilibration between application of microwave energy and resulted in reduced temperature and $\mathrm{M}_{52}$ variation between the four probe locations in an apple.

\subsection{Mortality of insects under different treatment conditions}

\subsubsection{B. tyroni experiments}

Applying process condition $\mathrm{T}_{\mathrm{a}}$ in three experimental replicates resulted in $100 \%$ mortality of Q-fly eggs and first instar larvae

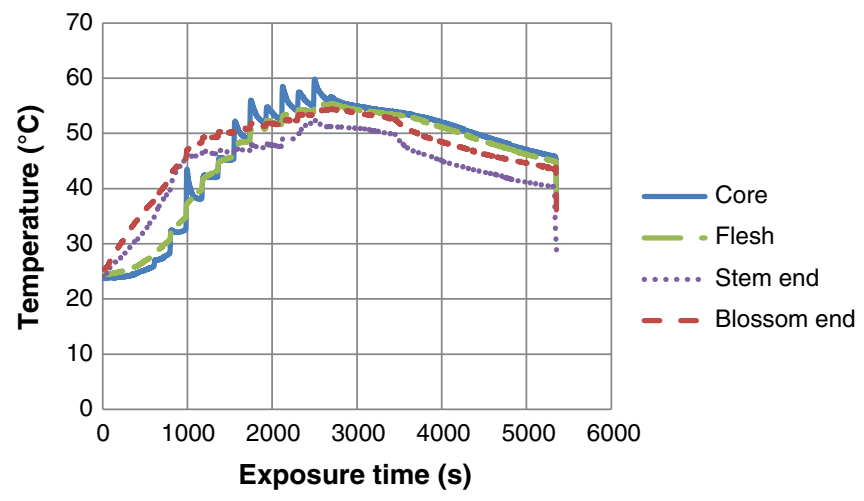

Fig. 5. Typical temperature profile of an apple at the core, under the peel at the stem (top) and the blossom end (bottom) and flesh.
(Table 2). In each experiment, more than 12,000 insects were tested, most of which were eggs. Disinfestation research requires testing of large numbers of insects (Heather \& Hallman, 2008) and quarantine authorities often require that at least 30,000 insects are treated without survivors for the development of treatment protocols. However, smaller numbers can be used to give an indication of efficacy levels in preliminary trials. The egg-only treatment treated eggs approximately $24 \mathrm{~h}$ after oviposition, whilst the treatments which contained eggs and first instars were treated approximately $48 \mathrm{~h}$ after oviposition and contained a mix of very mature eggs and newly hatched first instar larvae. Mature eggs have been shown to be the most tolerant life stage of $B$. tryoni to conventional heat treatments (Heather, Corcoran, \& Kopittke, 1997) and these trials show that the treatment was effective against both immature and mature eggs. The development of quarantine disinfestation treatments requires testing against all immature life stages and therefore, further research will be required to ensure that the treatment is also efficacious against the second and third instar larvae.

During microwave insect disinfestation trials, apples at an average initial temperature of $24.6{ }^{\circ} \mathrm{C}$ reached an average maximum temperature of $55.8{ }^{\circ} \mathrm{C}$. The average minimum $\mathrm{M}_{52}$ at the coldest spot was $38.87 \pm 22.11 \mathrm{~min}$. The high standard deviation is due to the exponential relationship between temperature and the $\mathrm{M}_{52}$ values as can be seen in Eq. (1).

\subsubsection{B. jarvisi experiments}

Three different microwave process conditions $\left(\mathrm{T}_{\mathrm{b}}, \mathrm{T}_{\mathrm{c}}\right.$ and $\left.\mathrm{T}_{\mathrm{d}}\right)$ were evaluated in this study and variable results were observed with B. jarvisi as summarised in Table 3.

From four trials with process condition $\mathrm{T}_{\mathrm{b}}$, two trials recorded $100 \%$ mortality, whilst the other trials recorded 99.97 and 99.92\%. Similarly, process condition $T_{c}$ was tested seven times and $100 \%$ mortality was achieved in five trials and in two trials mortality was 97.61 and $99.68 \%$. Process condition $\mathrm{T}_{\mathrm{d}}$ resulted in less than $100 \%$ mortality in all trials.

In cases where $100 \%$ mortality was not achieved using process conditions $T_{b}$ and $T_{c}$, the mortality was greater than $99 \%$ for Tb and greater than $97 \%$ for $T_{c}$. At least 2000 insects were treated in all experiments and most treated more than 5000 insects. In all trials except for one, mortality was $100 \%$ when only eggs were present, whilst there were survivors in trials with a mixture of eggs and first instars. This is most likely due to the age of the eggs at treatment. The egg-only treatments treated eggs about $24 \mathrm{~h}$ after oviposition, whilst the treatments which contained eggs and first instars were treated about $48 \mathrm{~h}$ after oviposition and contained very mature eggs and newly hatched firsts. Corcoran (2002) showed that eggs of $B$. jarvisi increase their heat tolerance with age and are particularly tolerant to heat when they have passed through $80 \%$ of their development.

$B$. jarvisi has been shown to be more heat tolerant than $B$. tryoni (Corcoran, 2002) and further experimentation is needed to identify conditions which result in $100 \%$ mortality. As for the Q-fly, further research on $B$. jarvisi must include the second and third instar larvae as quarantine treatments require that all immature life stages are tested.

Variability in the results indicates that in order to achieve a reproducible result of $100 \%$ mortality of $B$. jarvisi, it is necessary to reach an $M_{52}$ value in the coldest spot greater than 34 min (Fig. 6). The $M_{52}$ value at the coldest spot is a more reliable parameter to use for predicting mortality of $B$. jarvisi than using only the temperature reached at the coldest spot. This is because it is a measure of both temperature and time of exposure to the temperature of concern.

\subsection{Quality analyses of Granny Smith apples}

\subsubsection{Peel firmness}

The two treatments and the control showed a similar change in peel firmness during storage at $4{ }^{\circ} \mathrm{C}$ for 4 weeks as shown in Fig. 7. There were no significant differences in firmness between storage intervals 
Table 2

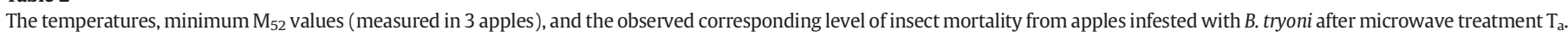

\begin{tabular}{|c|c|c|c|c|c|c|}
\hline $\begin{array}{l}\text { Initial } \\
\text { temperature } \\
\left({ }^{\circ} \mathrm{C}\right)\end{array}$ & $\begin{array}{l}\text { Maximum temperature } \\
\left({ }^{\circ} \mathrm{C}\right)\end{array}$ & $\begin{array}{l}\text { Minimum } \\
\mathrm{M}_{52} \\
(\mathrm{~min})\end{array}$ & $\begin{array}{l}\text { Proportion of each life stage } \\
\text { treated }^{\mathrm{a}}\end{array}$ & $\begin{array}{l}\text { Number of treated } \\
\text { fruit }\end{array}$ & $\begin{array}{l}\text { Estimated number of insects } \\
\text { treated }\end{array}$ & $\begin{array}{l}\text { Mortality } \\
(\%)\end{array}$ \\
\hline 23.5 & 55.1 & 23.6 & $\begin{array}{l}\text { E } 86 \% \\
\text { L1 14\% }\end{array}$ & 60 & 12,675 & 100 \\
\hline 26.4 & 56.3 & 70.2 & E 100\% & 60 & 16,330 & 100 \\
\hline 23.8 & 56.0 & 22.9 & $\begin{array}{l}\text { E 95\% } \\
\text { L1 5\% }\end{array}$ & 60 & 15,260 & 100 \\
\hline \multicolumn{7}{|l|}{ Average } \\
\hline 24.6 & 55.8 & 38.87 & & NA & NA & 100 \\
\hline
\end{tabular}

${ }^{\mathrm{a}} \mathrm{E}=$ eggs; $\mathrm{L} 1=$ first instar larvae.

$(\mathrm{p}=0.88)$ or treatments $(\mathrm{p}=0.92) . \mathrm{T} 1\left(\mathrm{~T}_{\mathrm{a}}+\right.$ cooling in water at $4{ }^{\circ} \mathrm{C}$ for $1 \mathrm{~h})$ and $\mathrm{T} 2\left(\mathrm{~T}_{\mathrm{a}}+\right.$ cooling at ambient temperature) were comparable to the untreated control samples. These results indicate that the microwave treatment and the subsequent cooling processes had a minimal effect on the peel firmness.

\subsubsection{Mesocarp firmness}

Mesocarp firmness significantly decreased from week 1 to week 2 and then gradually increased in week 3 and 4 and this trend was statistically significant ( $\mathrm{p}<0.01$; Fig. 8 heavy line). However, mesocarp firmness of apples subjected to treatments $\mathrm{T} 1$ and $\mathrm{T} 2$ followed a trend similar to the control and showed no significant difference $(p=.90)$. Similar to the peel firmness, the mesocarp firmness was not affected by the applied microwave treatment and cooling method.

\subsubsection{Weight loss}

The weight loss of apples was small and well below $1 \%$, but gradually increased with storage time in control, and treatments T1 and T2 (Fig. 9). The weight loss data were structured differently to that of the other quality parameters and individual models of weight loss or percentage weight loss for each of the four weeks were fitted. This revealed that air cooled apples had significantly less weight loss than the controls in each of the first three weeks, whilst the hydro-cooled apples lost significantly more weight over the first week and less in the second. No other statistically significant differences were observed. This higher weight loss for the hydro-cooled apples may have been caused by initial water absorption during cooling, which was then lost again during the early stages of storage. NSW Food Authority (2006) recommends washing produce with water at a temperature $5-10{ }^{\circ} \mathrm{C}$ higher than that of the product to prevent absorption of washing water by fruit and vegetables during washing.

Workneh and Ostjoff (2010) mentioned that water loss caused by transpiration plays a key role in physiological changes in addition to the weight loss. It is also important to note that horticultural crops lose mass after harvest, partly due to transpiration, and partly due to respiration. Such mass loss can have adverse effects on quality, e.g. faster ripening or increased incidences of physiological disorders and rots (Johnston \& Banks, 1998).

\subsubsection{Total soluble solids ( ${ }^{\circ}$ Brix)}

Total soluble solid content was not significantly affected by the microwave treatment and cooling method $(\mathrm{p}=0.44)$ as shown in

Table 3

The temperatures, $\mathrm{M}_{52}$, and the observed level of insect mortality in B. jarvisi fruit fly infested apples after microwave treatments $\left(\mathrm{T}_{\mathrm{b}}-\mathrm{T}_{\mathrm{d}}\right)$.

\begin{tabular}{|c|c|c|c|c|c|c|c|}
\hline Treatment & $\begin{array}{l}\text { Initial temp } \\
\left({ }^{\circ} \mathrm{C}\right)\end{array}$ & $\begin{array}{l}\text { Max temp } \\
\left({ }^{\circ} \mathrm{C}\right)\end{array}$ & $\begin{array}{l}\text { Min } M_{52} \\
(\min )\end{array}$ & $\begin{array}{l}\text { Proportion of each life stage } \\
\text { treated }^{\mathrm{a}}\end{array}$ & $\begin{array}{l}\text { Number of treated } \\
\text { fruit }\end{array}$ & $\begin{array}{l}\text { Estimated number of insects } \\
\text { treated }\end{array}$ & $\begin{array}{l}\text { Mortality } \\
(\%)\end{array}$ \\
\hline $\mathrm{T}_{\mathrm{b}}$ & 24.4 & 53.0 & 13.5 & E 100\% & 30 & 2445 & 100.00 \\
\hline $\mathrm{T}_{\mathrm{b}}$ & 24.0 & 53.1 & 10.6 & $\begin{array}{l}\text { E 61\% } \\
\text { L1 39\% }\end{array}$ & 30 & 7685 & 99.97 \\
\hline $\mathrm{T}_{\mathrm{b}}$ & 25.7 & 55.4 & 7.0 & E 100\% & 60 & 42,490 & 99.92 \\
\hline $\mathrm{T}_{\mathrm{b}}$ & 25.8 & 53.8 & 17.2 & E 100\% & 15 & 5306 & 100.00 \\
\hline $\mathrm{T}_{\mathrm{c}}$ & 24.9 & 54.5 & 34.2 & E 100\% & 15 & 5306 & 100.00 \\
\hline $\mathrm{T}_{\mathrm{c}}$ & 24.8 & 52.8 & 14.2 & $\begin{array}{l}\text { E } 60 \% \\
\text { L1 } 40 \%\end{array}$ & 15 & 9288 & 97.61 \\
\hline $\mathrm{T}_{\mathrm{c}}$ & 24.4 & 53.5 & 24.6 & $\begin{array}{l}\text { E 60\% } \\
\text { L1 40\% }\end{array}$ & 15 & 9288 & 99.68 \\
\hline $\mathrm{T}_{\mathrm{C}}$ & 24.1 & 52.1 & 20.7 & E $100 \%$ & 15 & 3234 & 100.00 \\
\hline $\mathrm{T}_{\mathrm{c}}$ & 24.1 & 51.7 & 20.9 & E $100 \%$ & 15 & 3234 & 100.00 \\
\hline $\mathrm{T}_{\mathrm{c}}$ & 24.3 & 52.6 & 19.6 & E 100\% & 15 & 3234 & 100.00 \\
\hline $\mathrm{T}_{\mathrm{c}}$ & 24.2 & 53.2 & 26.7 & E 100\% & 15 & 3234 & 100.00 \\
\hline $\mathrm{T}_{\mathrm{d}}$ & 25.1 & 53.2 & 33.5 & $\begin{array}{l}\text { E } 71 \% \\
\text { L1 } 29 \%\end{array}$ & 15 & 5306 & 99.96 \\
\hline $\mathrm{T}_{\mathrm{d}}$ & 25.5 & 53.6 & 24.6 & $\begin{array}{l}\text { E 60\% } \\
\text { L1 40\% }\end{array}$ & 15 & 9288 & 98.10 \\
\hline $\mathrm{T}_{\mathrm{d}}$ & 24.2 & 51.7 & 13.7 & $\begin{array}{l}\text { E } 60 \% \\
\text { L1 } 40 \%\end{array}$ & 15 & 9288 & 99.29 \\
\hline $\mathrm{T}_{\mathrm{d}}$ & 23.9 & 52.4 & 18.17 & $\begin{array}{l}\text { E } 71 \% \\
\text { L1 } 29 \%\end{array}$ & 15 & 6649 & 99.94 \\
\hline $\mathrm{T}_{\mathrm{d}}$ & 24.4 & 50.1 & 6.1 & $\begin{array}{l}\text { E 71\% } \\
\text { L1 29\% }\end{array}$ & 15 & 6649 & 97.88 \\
\hline $\mathrm{T}_{\mathrm{d}}$ & 24.4 & 52.7 & 18.0 & $\begin{array}{l}\text { E } 71 \% \\
\text { L1 } 29 \%\end{array}$ & 15 & 6649 & 99.79 \\
\hline $\mathrm{T}_{\mathrm{d}}$ & 24.4 & 53.4 & 17.7 & $\begin{array}{l}\text { E } 71 \% \\
\text { L1 29\% }\end{array}$ & 15 & 6649 & 99.71 \\
\hline
\end{tabular}

\footnotetext{
${ }^{\mathrm{a}} \mathrm{E}=$ eggs; $\mathrm{L} 1$ = first instar larvae.
} 


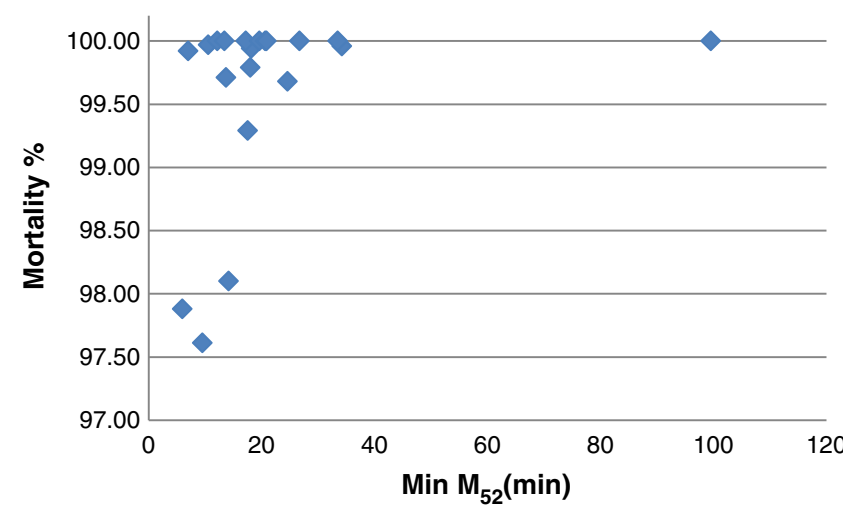

Fig. 6. Minimum $\mathrm{M}_{52}$ value at the coldest spot in an apple and the corresponding mortality of B. jarvisi.

Fig. 10. Total soluble solid content showed significant differences between storage intervals. Measurements for each treatment decreased initially before rising until the third week and then decreased again except for the air cooled apples, which recorded one high value. This overall trend was statistically significant $(\mathrm{p}=0.03$ ).

The change in the total soluble solids maybe related to the fact that plants are living tissues that are subjected to continuous changes, partly caused by respiration. Workneh and Ostjoff (2010) stated that respiration is a natural process in all living organisms which breaks down organic matter such as sugars into simpler products. According to Wills, McGlasson, Graham, Lee, and Hall (1989) the storage life of produce is inversely related to the respiration rate, which can be reduced by storing the commodities at lower temperatures, increasing carbon dioxide, and reducing oxygen concentrations (Kassim, Workeneh, \& Bezuidenhout, 2013).

\subsection{5. $\mathrm{pH}$}

Fig. 11 shows that $\mathrm{pH}$ changes significantly during storage at $4{ }^{\circ} \mathrm{C}$ $(\mathrm{p}<0.001)$. For each treatment and the control, $\mathrm{pH}$ decreased initially up to the third week before rising slightly in the fourth week. This change in $\mathrm{pH}$ may have been caused by natural breakdown of fruit components over storage time. A significant difference was observed between treatments $(\mathrm{p}<0.01)$. The $\mathrm{pH}$ values of $\mathrm{T} 1$ and T2 were significantly higher than those of the control sample during weeks 3 and 4.

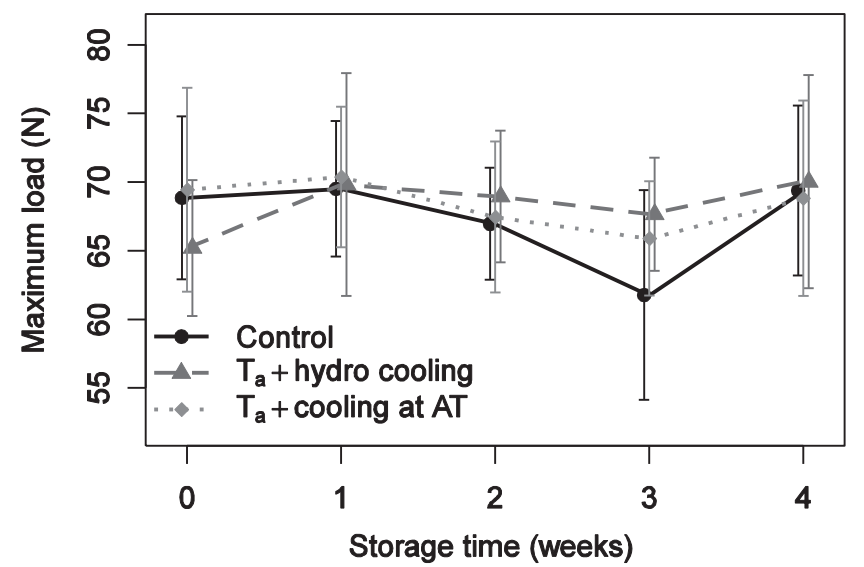

Fig. 7. Peel firmness (maximum load) of untreated apples (control: black dots with solid averaged line) and apples subjected to microwave treatment $T_{a}$ and subsequent hydro cooling (grey triangles with dashed averaged line) or cooling at ambient temperature (light grey dots with dotted averaged line) during storage at $4{ }^{\circ} \mathrm{C}$ for 4 weeks. Data points are plotted alongside each other to avoid overlap, but were taken at a whole number of weeks.

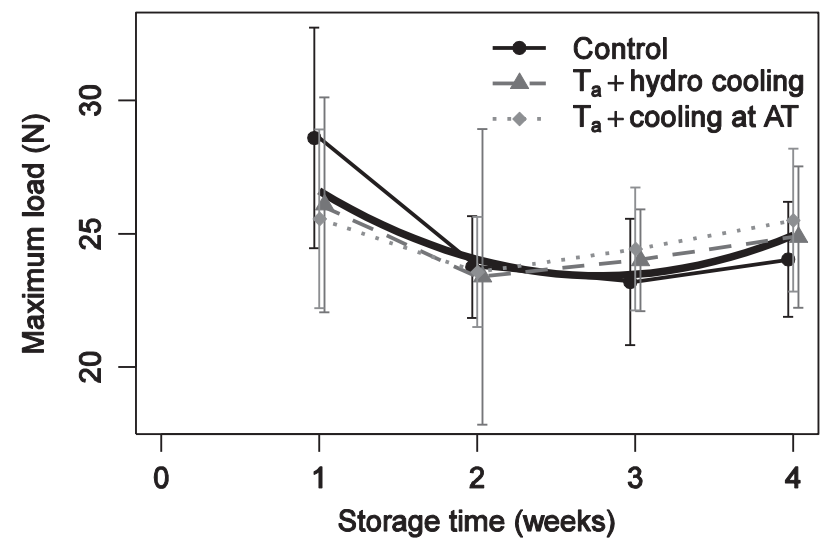

Fig. 8. Mesocarp firmness (maximum load) of untreated apples (control) and apples subjected to microwave treatment $\mathrm{T}_{\mathrm{a}}$ and subsequent hydro cooling or cooling at ambient temperature stored at $4{ }^{\circ} \mathrm{C}$ for 4 weeks. The heavy line indicates the overall trend.

There was no statistically significant difference in $\mathrm{pH}$ between apples given the hydro-cooling and air cooling treatments $(\mathrm{p}=0.75)$.

\subsubsection{Ion leakage}

Whilst all three treatments showed a drop in ion leakage initially, ion leakage of microwave treated and hydro-cooled or air cooled samples stabilised after week one of storage. Fig. 12 shows a very clear effect of the treatments. The ion leakage of the control group gradually increased after two weeks of storage, reaching levels higher than the recorded levels at the beginning of the experiment. Ion leakage differed each week $(\mathrm{p}<0.001)$. Taking the time effect into account, a statistically significant cubic interaction with treatment was observed $(p<0.001)$. However, there was no statistically significant difference between the effects of hydro and air cooling $(\mathrm{p}=0.13)$. An increase in ion leakage has been observed in plant tissues subjected to high temperature injury and chilling injuries (Inaba \& Crandall, 1988: Saltveit, 2002). Immediately following hot water treatment at $39-45^{\circ} \mathrm{C}$ for $60 \mathrm{~min}$, ion leakage from mature-green tomato pericarp gradually decreased, however, ion leakage increased slightly following the $48{ }^{\circ} \mathrm{C}$ treatment. At the redripe stage, fruit treated at $48{ }^{\circ} \mathrm{C}$ had the highest percentage ion leakage, indicating possible high-temperature injury (McDonald et al., 1995).

\subsubsection{External and internal appearance of apples}

The microwave treated apples were comparable to untreated apple in external appearance and colour (Fig. 13). Chlorophylls are responsible for the characteristic green colour of fruits and vegetables (Hung,

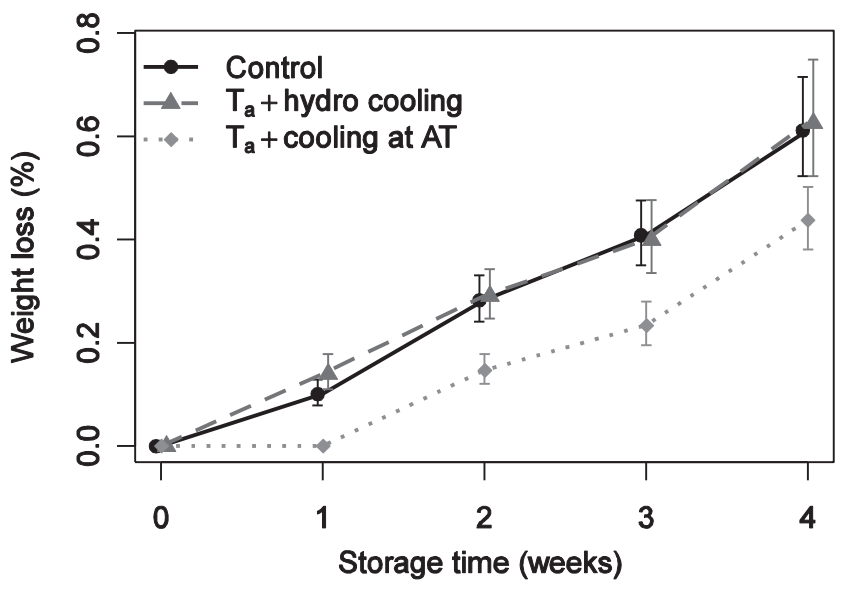

Fig. 9. Weight loss of untreated apples (control) and apples subjected to microwave treatment $\mathrm{T}_{\mathrm{a}}$ and subsequent hydro cooling or cooling at ambient temperature (AT). 


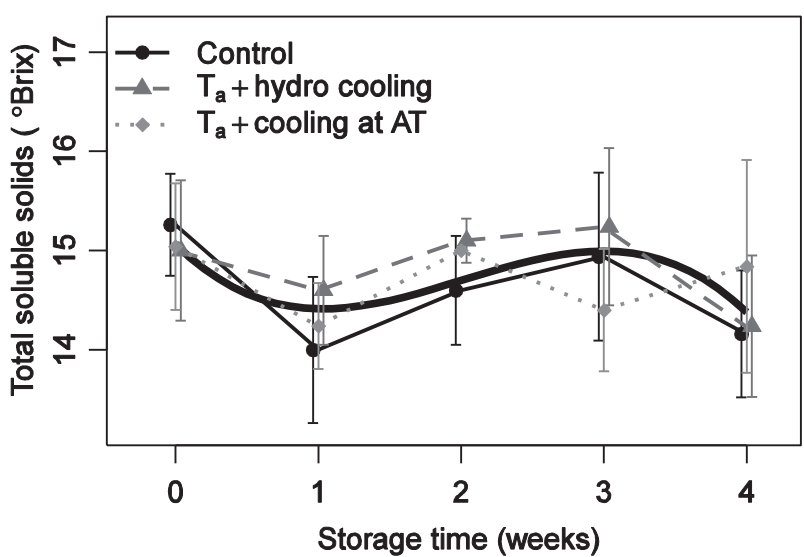

Fig. 10. Total soluble solid content of untreated apples (control) and apples subjected to microwave treatment $\mathrm{T}_{\mathrm{a}}$ and subsequent hydro cooling or cooling at ambient temperature. The heavy line indicates the overall trend.

Morita, Shewfelt, Resurreccion, \& Prussia, 1995). Loss of chlorophyll in the peel plastids results in changes in colour of Granny Smith apples. The catabolism of chlorophyll is affected by the increase of chlorophyllase activity during the ripening of fruit, both on the tree and during prolonged storage (Ihl, Etcheberrigaray, \& Bifani, 1994). Preharvest conditions and postharvest treatments affect skin greenness. Postharvest treatments such as dipping in diphenylamine emulsion (Lurie, Klein, \& Ben-Arie, 1989) and heat treatments (Lurie, Fallik, \& Klein, 1996; Mignani \& Zocchi, 1998) affect the green colour of apples. Chlorophyll pigments are highly susceptible to degradation during heat processing $\left(\sim 100^{\circ} \mathrm{C}\right)$, resulting in colour changes. The heat mediated degradation is caused by the conversion of chlorophylls to pheophytins and as a result the green colour of fruit and vegetables turns to olive green (Gunawan \& Barringer, 2000). However, elevated temperature at $50{ }^{\circ} \mathrm{C}$ could reduce chlorophyll degradation due to the suppression of chlorophyll degrading enzyme activities (Funamoto, Yamauchi, Shigenaga, \& Shigyo, 2002).

The internal colour of control and microwave treated apples was similar and showed no internal discolouration (Fig. 14). Internal discolouration of intact apples generally occurs due to a physiological disorders resulting from exposure to high $\mathrm{CO}_{2}$ during long term storage of Fuji, Cox's Orange Pippin, Braeburn and Jonathan apples (UC PTC website, 2014). Treatment of apple (cv Shafie) slices at $50{ }^{\circ} \mathrm{C}$ for $2 \mathrm{~min}$ inhibited the enzymatic browning in fresh cut apple (Javdani, Ghasemnezhad, \& Zare, 2013).

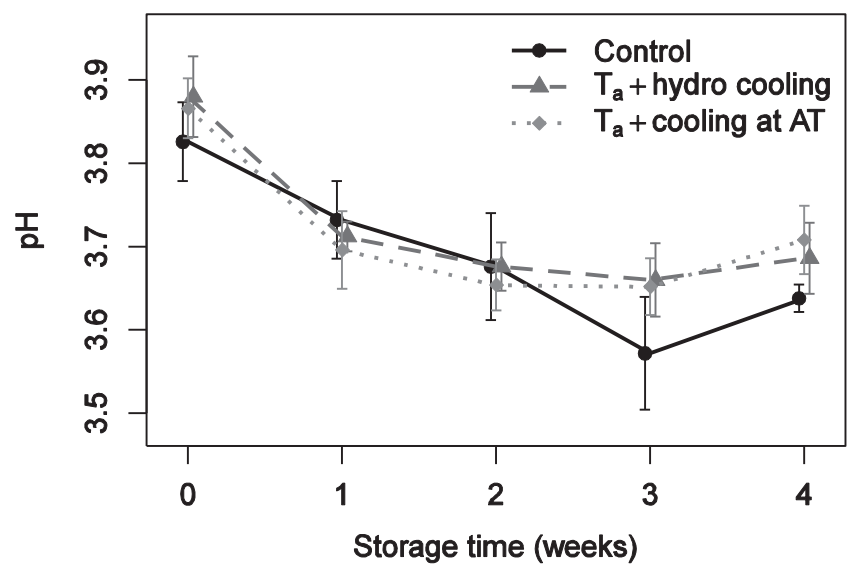

Fig. 11. The pH of untreated apples (control) and apples subjected to microwave treatment $\mathrm{T}_{\mathrm{a}}$ and subsequent hydro cooling or cooling at ambient temperature.

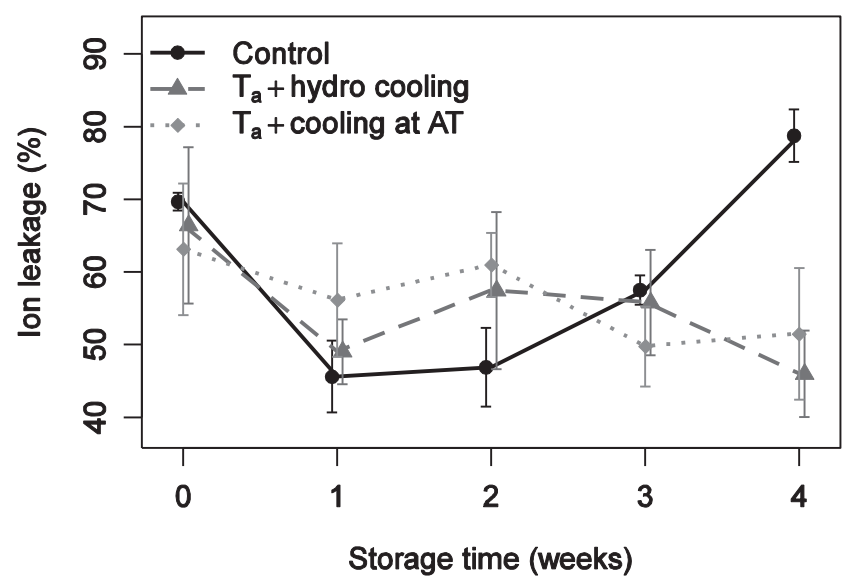

Fig. 12. Ion leakage of untreated apples (control) and apples subjected to microwave treatment $\mathrm{T}_{\mathrm{a}}$ and subsequent hydro cooling or cooling at ambient temperature.

\subsection{Cost estimation}

Preliminary cost estimates of capital expenses as well as operating expenses have been evaluated. A microwave system, suitable for processing 5 tonnes of apples per day, and the required specific energy input of $\sim 100 \mathrm{~kJ} / \mathrm{kg}$, requires approximately $10 \mathrm{~kW}$ nominal power output. Equipment of this size has an estimated capital cost of US\$200,000. The electric power consumption to achieve the required mortality of FF was estimated to be approximately US\$ 0.026 per $\mathrm{kg}$ of treated apples. This is comparable to the cost of chemical spray or dip treatment, which is approximately US\$ 0.03 . However, the combined hot air and microwave technology has the advantage of being more environmentally friendly and chemical residue free. Furthermore, chemical treatment will eventually be phased out, and alternative, cost-effective physical treatments are required.

\section{Conclusions}

This study has established that the continuous pilot scale pentagonal microwave system can raise the temperature of apples uniformly in a significantly shorter time than in conventional heat treatments, provided appropriate microwave heating protocols are used. Microwave treatment with a tunnel temperature of $40^{\circ} \mathrm{C}$ and a specific energy of $112 \mathrm{~kJ} /$ $\mathrm{kg}$ effectively achieved $100 \%$ mortality of $B$. tryoni in 3 replicate experiments. The mortality achieved with B. jarvisi was variable between 97 and $100 \%$ with microwave treatments at a tunnel temperature of $40{ }^{\circ} \mathrm{C}$ and a specific energy $103 \mathrm{~kJ} / \mathrm{kg}$ or a tunnel temperature of $45^{\circ} \mathrm{C}$ and a specific energy of $103 \mathrm{~kJ} / \mathrm{kg}$ in replicate experiments. In summary the treatments had no observed effects on total soluble solids, flesh or peel firmness of the treated apples. The treated apples did have slightly higher $\mathrm{pH}$ and lower ion leakage than the controls after 3 or 4 weeks; however, there was no significant difference between the hydrocooled and air cooled apples. Finally, there were slight differences in weight loss for the different treatments. The most noticeable difference was that microwave treated and air cooled apples lost less weight than the microwave treated and hydro-cooled apples or the control samples.

Continuous microwave processing at appropriate processing conditions and equipment configuration offers great value for the disinfestation of B. tryoni and B. jarvisi in horticultural produce. This study has shown that microwave processing can be used for effective insect disinfestation at significantly reduced treatment times and processing costs compared to vapour heat treatment or hot water dipping, therefore providing quality and economical benefits. The cost of a microwave system is comparatively lower than that of the vapour heat and ionising radiation treatment facilities. Microwave treatment leaves no residues, 


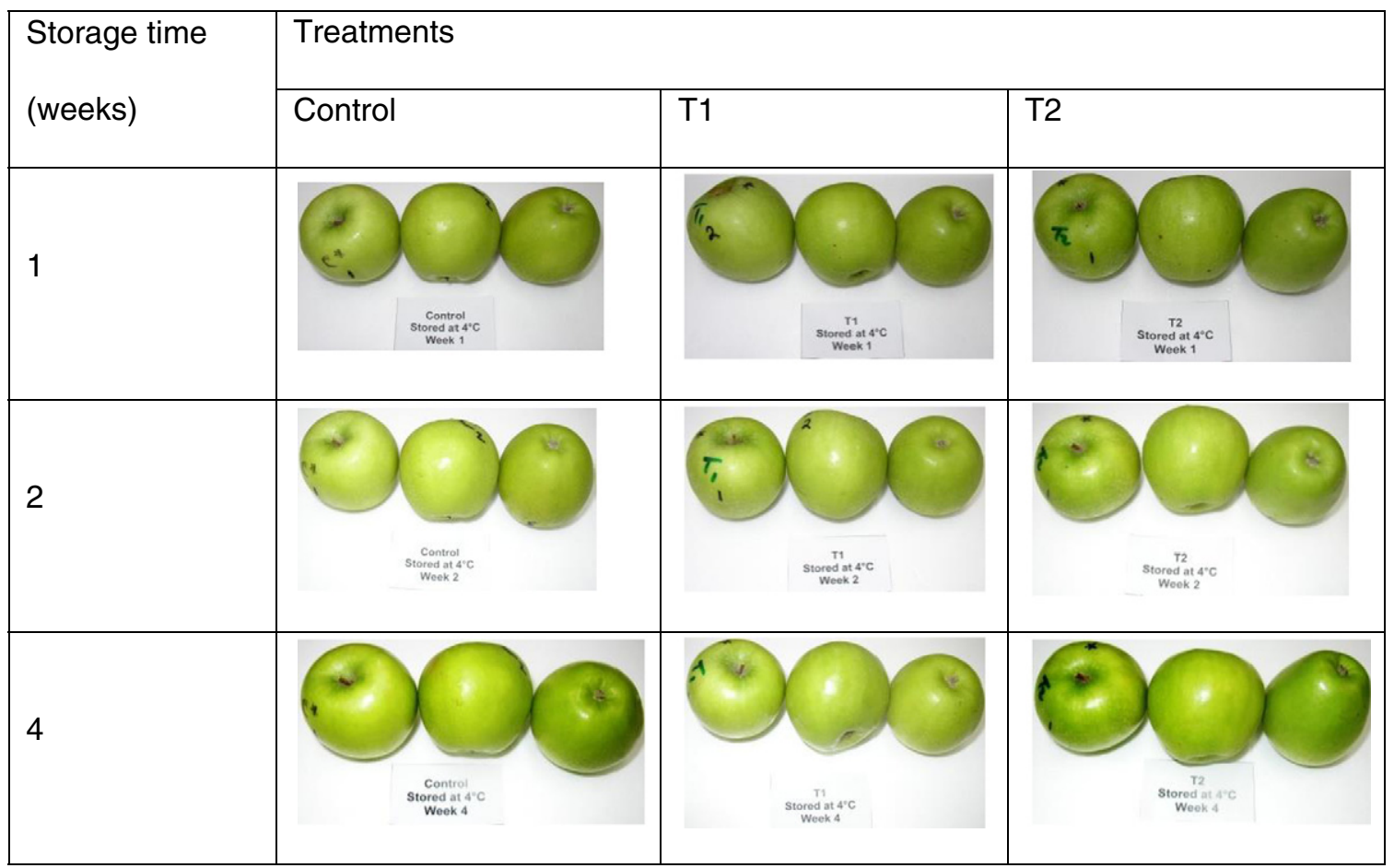

Fig. 13. External appearance of control apples and apples subjected to microwave treatment and subsequent cooling treatments (T1 and $\mathrm{T} 2$ ) during storage at $4{ }^{\circ} \mathrm{C}$ for 4 weeks.

offering environmental and health benefits compared to existing chemical treatments. A further advantage of the continuous microwave process used in this study is that it can be installed in pack houses as opposed to the current centralised batch treatment associated with vapour heat or ionising radiation. This approach also has the potential to be utilised as an alternative treatment for other quarantine pests specific to export destinations.
More studies are required to determine the $z$ values for fruit flies, optimise processing conditions and treatment protocols and for scaling-up to commercial applications. The work reported in this study provides proof of concept; however, comparative trials incorporating all immature life stages and large scale fruit fly disinfestation trials against the most tolerant life stage need to be conducted to validate this approach as an approved quarantine method.

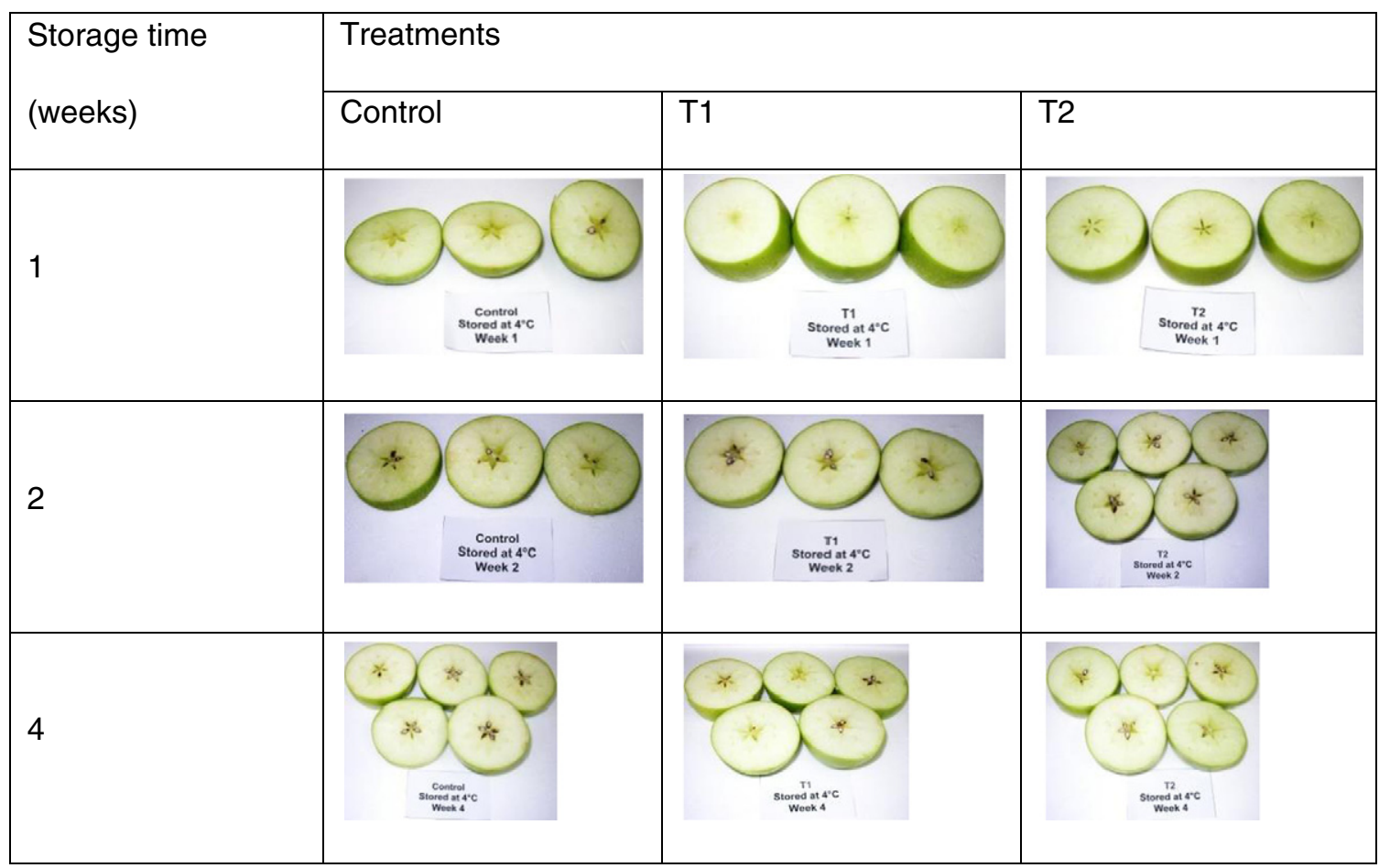

Fig. 14. Internal appearance of control apples and apples subjected to microwave treatment and subsequent cooling treatments (T1 and $\mathrm{T} 2$ ) during storage at $4{ }^{\circ} \mathrm{C}$ for 4 weeks. 


\section{Acknowledgement}

This study has been conducted with financial support from CSIRO, Department of Environment and Primary Industries, Victoria and Department of Agriculture, Fisheries and Forestry, Queensland. Authors also wish to acknowledge the technical expertise provided by Mr. Phil Muller of CSIRO on modifying the microwave unit and Mr. Lloyd Simons for industry engagement.

\section{References}

Amstrong, J.W., \& Mangan, R.L. (2007). Commercial quarantine heat treatments. In J. Tang, E. Mitcham, S. Wang, \& S. Lurie (Eds.), Heat treatments for postharvest pest control: theory and practice (pp. 311-340). Wallingford, UK: CAB International.

Anon (2011). Suspension of products containing dimethoate and associated label approvals. Commonwealth of Australia Gazette No. APVMA 20 (Tuesday 11 October 2011).

Birla, S.L., Wang, S., Tang, J., \& Hallman, G. (2004). Improving heating uniformity of fresh fruit in radio frequency treatments for pest control. Postharvest Biology and Technology, 33(2), 205-217.

Corcoran, R.J. (2002). Fruit fly (Diptera: Terphritidae) response to quarantine heat treatment. (Ph D Thesis) The University of Queensland.

Corcoran, R.J., Heather, N.W., \& Heard, T.A. (1993). Vapour heat treatment of zucchini infested with Bactrocera cucumis (Diptera: Tephritidae). Journal of Economic Entomology, 86(1), 66-69.

Ekman, J.H., \& Pristijono, P. (2010). Combining radio frequency heating and cool storage to disinfest cherries against Queensland fruit fly. Acta Horticulturae, 877, 1411-1448.

Food Authority, N.S.W. (2006). http://www.foodauthority.nsw.gov.au/_documents/ industry_pdf/cleaning_sanitising_fresh_produce.pdf

Funamoto, Y., Yamauchi, N., Shigenaga, T., \& Shigyo, M. (2002). Effects of heat treatment on chlorophyll degrading enzymes in stored broccoli (Brassica oleracea L.). Postharvest Biology and Technology, 24(2), 163-170.

Gazit, Y., Rossler, Y., Wang, S., Tang, J., \& Lurie, S. (2004). Thermal death kinetics of egg and third instar Mediterranean fruit fly (Diptera: Tephritidae). Journal of Economic Entomology, 97(5), 1540-1546.

Australian Government (2014). http://www.agriculture.gov.au/agriculture-food/ag-vetchemicals/international/methyl-bromide (last visited 04 Dec 2014)

Gunawan, M.I., \& Barringer, S.A. (2000). Green colour degradation of blanched broccoli (Brassica oleracea) due to acid and microbial growth. Journal of Food Processing and Preservation, 24(3), 253-263.

Hansen, J. (1992). Heating curve models of quarantine treatments against insect pests. Journal of Economic Entomology, 85(5), 1846-1854.

Heather, N.W., \& Corcoran, R.J. (1985). Dacus tryoni. In P. Singh, \& R.F. Moore (Eds.), Handbook of Insect Rearing, Volume 2. (pp. 41-48). Elsevier: Amsterdam.

Heather, N.W., Corcoran, R.J., \& Kopittke, R.A. (1997). Hot air disinfestation of Australian "Kensington" mangoes against two fruit flies (Diptera: Tephritidae). Postharvest Biology and Technology, 10, 99-105.

Heather, N.W., \& Hallman, G.J. (2008). Pest management and phytosanitary trade barriers. United Kingdom: CABI.

Hung, Y.C., Morita, K., Shewfelt, R., Resurreccion, A.V.A., \& Prussia, S. (1995). Sensory and instrumental evaluation of apple color. Journal of Sensory Studies, 10, 15-23.

Ihl, M., Etcheberrigaray, C., \& Bifani, V. (1994). Chlorophyllase behavior on Granny Smith apples. Acta Horticulturae, 368, 59-68.

Ikediala, J.N., Tang, J., Neven, L.G., \& Drake, S.R. (1999). Quarantine treatment of cherries using $915 \mathrm{MHz}$ microwaves: temperature mapping, codling moth mortality and fruit quality. Postharvest Biology and Technology, 16(2), 127-137.

Ikediala, J.N., Tang, J., \& Wig, T. (2000). A heating block system for studying thermal death kinetics of insect pests. Transactions of the ASABE, 43(2), 351-358.

Inaba, M., \& Crandall, P.G. (1988). Electrolyte leakage as an indicator of high-temperature injury to harvested mature green tomatoes. Journal of the American Society for Horticultural Science, 113, 96-99.
ISPM No 18 (2003). http://www.acfs.go.th/sps/downloads/23881_ISPM_18_E.pdf

ISPM No 28 Part 3 (2009). https://www.ippc.int/sites/default/files/documents/ 1323950176_PT_03_2009_En_2011-12-01_Reforma.pdf

Javdani, Z., Ghasemnezhad, M., \& Zare, S. (2013). A comparison of heat treatment and ascorbic acid on controlling enzymatic browning of fresh-cuts apple fruit International Journal of Agriculture and Crop Sciences, 5(3), 186-193.

Johnston, J.W., \& Banks, N.H. (1998). Selection of a surface coating and optimisation of its concentration for use on 'Hass' avocado (Persea Americana Mill.) fruit. New Zealand Journal of Crop and Horticultural Science, 26(2), 143-151. http://dx.doi.org/10.1080/ 01140671.1998.9514051

Kassim, A., Workeneh, T.S., \& Bezuidenhout, C.N. (2013). A review on postharvest handling of avocado fruit. African Journal of Agricultural Research, 8, 2385-2402.

Knoerzer, K., Regier, M., \& Schubert, H. (2008). A computational model for calculating temperature distributions in microwave food applications. Innovative Food Science \&' Emerging Technologies, 9(3), 374-384.

Lurie, S., Fallik, E., \& Klein, J.D. (1996). The effect of heat treatment on apple epicuticular wax and calcium uptake. Postharvest Biology and Technology, 8, 271-277.

Lurie, S., Klein, J., \& Ben-Arie, R. (1989). Physiological changes in diphenylamine treated Granny Smith apples. Israel Journal of Botany, 38, 199-207.

McDonald, R.E., McCollum, T.G., \& Baldwin, E.A. (1995). Temperature of water heat treatments influences tomato fruit quality following low-temperature storage. Postharvest Biology and Technology, 16, 147-155.

Mignani, I., \& Zocchi, G. (1998). Prestorage heat treatment on apples cv. Granny Smith. In E.J. Woltering (Ed.), Current status and future prospects: Proceedings of Workshop 19-22 October, 1994, Oosterbeek, The Netherlands: COST 94: The Postharvest Treatment of Fruit and Vegetables (pp. 413-418). Luxemburg: Office for Official Publications of the European Communities.

Ohlsson, T. (1983). Fundamentals of microwave cooking. Microwave World, 4(2), 4-9.

Ohlsson, T., \& Risman, P.O. (1978). Temperature distribution of microwave heating spheres and cylinders. Journal of Microwave Power and Electromagnetic Energy, 13(4), 303-309.

Plant Health Australia (2008). Draft national fruit fly strategy. URL. Last visited on 20 March 2014. http://www.planthealthaustralia.com.au/wp-content/uploads/2012/ 12/Draft-National-Fruit-Fly-Strategy-Mar-2008.pdf

Saltveit, M.E. (2002). The rate of ion leakage from chilling-sensitive tissue does not immediately increase upon exposure to chilling temperatures. Postharvest Biology and Technology, 26(3), 295-304.

Sharp, J.L., Robertson, J.L., \& Preisler, H.K. (1999). Mortality of mature third instar Caribbean fruit fly (Diptera: Tephritidae) exposed to microwave energy. Canadian Entomologist, 131(1), 71-77.

Sutherst, R.W., Collyer, B.S., \& Yonow, T. (2000). The vulnerability of Australian horticulture to the Queensland fruit fly, Bactrocera (Dacus) tryoni, under climate change. Australian Journal of Agricultural Research, 51(4), 467-480.

Tang, J., Ikediala, J.N., Wang, S., Hansen, J.D., \& Cavalieri, R.P. (2000). High-temperatureshort-time thermal quarantine methods. Postharvest Biology and Technology, 21(1) 129-145.

The UC Davis Postharvest Technology Center (UC PTC) (). Apple: internal browning website, last visited on 20 March 2014. http://postharvest.ucdavis.edu/produce_ information/Fruit_Physiological__Disorders/Apple_InternalBrowning/

Tran, V. N. (1984). System for the microwave treatment of materials. US Patent, $4,631,380$.

Varith, J., Sirikajornjaru, W., \& Kiatsiriroat, T. (2007). Microwave-vapor heat disinfestation on oriental fruit fly eggs in mangoes. Journal of Food Processing and Preservation, 31(3), 253-269.

Wills, R.B.H., McGlasson, W.B., Graham, D., Lee, T.H., \& Hall, E.G. (1989). Postharvest: an introduction to the physiology and handling of fruit and vegetables. Oxford: BSP Professional Books (174 pp.)

Workneh, T.S., \& Ostjoff, G. (2010). A review on integrated agro-technology of vegetables. African Journal of Biotechnology, 9, 9307-9327. 